\title{
Kinerja Reproduksi Sapi Betina dan Performa Pedet pada Usaha Budi Daya Sapi Potong di Kabupaten Sigi
}

\section{(Reproductive Performance of Cows and Calves on the Business of Beef Cattle Breeding in the District Sigi)}

Takdir M, Haryono P, Ishak ABL

Balai Pengkajian Teknologi Pertanian Sulawesi Tengah

Jl. Lasoso No. 62, Sigi Biromaru, Kabupaten Sigi, Sulawesi Tengah 94364 dhirdhar31313@gmail.com

\begin{abstract}
The study was aimed to determine the reproductive performance of cows and the performance of calves in the centre of beef cattle production in Central Sulawesi. The research was conducted in Pandere village, subdistrict Gumbasa, Sigi District in 2015-2016. Data collection was done by interviewing 30 respondents using a structured questionnaire, recording, measurement and observation. Data collected consist of: the characteristics of the respondent farmers, reproductive performance and linear body size heifer and calf. The results showed most respondents worked as a farmer, aged on average 41.3 years old, a high school education level, experience of raising 16.2 years with an average ownership of livestock 2-4 cows per person. Reproductive performance of cows showed body condition score (BCS) 3.5, estrus after birth 2.9 months, postpartum mating 3.3 months, services per conception (S/C) of 2.5 times, days open (DO) 7.2 months and the calving interval (CI) of 16.5 months. Cows have an average age of 3.52 years have $234.3 \mathrm{~kg}$ body weight, chest circumference $146.2 \mathrm{~cm}$, height $121.4 \mathrm{~cm}, 55.9 \mathrm{~cm}$ wide pelvis and body length of $100.7 \mathrm{~cm}$. Performance of calves born during the years 2015-2016 have a range of 22.29 to $25.07 \mathrm{~kg}$ birth weight, body length of 54.15 to $54.53 \mathrm{~cm}$ and a height of 59.46 to $62.43 \mathrm{~cm}$. Concluded reproductive performance of cows in the breeding of beef cattle farmers is in lower categories. Linear body size cows corresponding to ISO standard value, performance linear birth weight and body size calf born during the years 2015-2016 was quite good.
\end{abstract}

Key Words: Reproductive, Performance, Breeding, Beef Cattle

\begin{abstract}
ABSTRAK
Penelitian bertujuan untuk mengetahui kinerja reproduksi sapi betina dan performa pedet pada usaha perbibitan sapi potong di salah satu wilayah kawasan pengembangan peternakan sapi potong Sulawesi Tengah. Penelitian dilaksanakan selama tahun 2015-2016 di Desa Pandere, Kecamatan Gumbasa, Kabupaten Sigi, Provinsi Sulawesi Tengah. Pengumpulan data dengan cara wawancara 30 peternak responden menggunakan daftar pertanyaan terstruktur (kuesioner), pencatatan, pengukuran dan pengamatan. Data yang dikumpulkan meliputi data karakteristik responden, kinerja reproduksi dan ukuran linier tubuh sapi betina serta performa pedet. Hasil penelitian menunjukkan sebagian besar responden bekerja sebagai petani, berumur rata-rata 41,3 tahun, tingkat pendidikan SLTA, pengalaman beternak 16,2 tahun dan rata-rata kepemilikan ternak 2-4 ekor per orang. Kinerja reproduksi sapi betina menunjukkan skor kondisi tubuh 3,5, berahi setelah beranak 2,9 bulan, kawin setelah beranak 3,3 bulan, service per conception 2,5 kali, masa kosong 7,2 bulan dan jarak beranak 16,5 bulan. Sapi betina berumur rata-rata 3,52 tahun memiliki bobot badan $234,3 \mathrm{~kg}$, lingkar dada $146,2 \mathrm{~cm}$, tinggi badan $121,4 \mathrm{~cm}$, lebar panggul $55,9 \mathrm{~cm}$ dan panjang badan $100,7 \mathrm{~cm}$. Performa pedet memiliki kisaran bobot badan 22,29-25,07 kg, panjang badan $54,15-54,53 \mathrm{~cm}$ dan tinggi badan 59,46-62,43 cm. Disimpulkan kinerja reproduksi sapi betina pada perbibitan sapi potong yang dikelola peternak rakyat relatif masih rendah. Ukuran linier tubuh sapi betina sesuai nilai standar SNI, performa pedet yang lahir selama tahun 2015-2016 cukup baik.
\end{abstract}

Kata Kunci: Reproduksi, Performa, Perbibitan, Sapi Potong 


\section{PENDAHULUAN}

Usaha peternakan sapi potong di Indonesia didominasi oleh usaha peternakan berskala kecil dengan jumlah rumah tangga peternak sebesar 4.204.213 orang (PSPK 2011) yang menguasai lebih dari 98\% ternak di Indonesia. Kondisi demikian merupakan salah satu peluang untuk mencapai target dan sasaran utama dari program pengembangan kawasan peternakan khususnya komoditas sapi potong, yakni peningkatan populasi dan produksi daging dalam negeri.

Sulawesi Tengah merupakan salah satu wilayah untuk pengembangan kawasan peternakan sapi potong di kawasan Timur Indonesia. Populasi sapi potong di Sulawesi Tengah relatif meningkat selama kurun waktu 2012-2015 (BPS Sulteng 2016) dengan tingkat pertumbuhan mencapai 3,53\% dan jumlah populasi mencapai 311.328 ekor (Ditjennak \& Keswan 2016). Populasi tersebut tersebar di 13 kabupaten/kota, dengan populasi tertinggi berada di 6 kabupaten yang merupakan wilayah diprioritaskan untuk pengembangan kawasan peternakan sapi potong di Provinsi Sulawesi Tengah (Kementan RI 2012) yakni; Kabupaten Banggai (73.805 ekor), Donggala (38.346 ekor), Sigi (29.186 ekor), Morowali-Morowali Utara (28.908 ekor), Parigi Mautong (27.477 ekor) dan Tojo Una Una (25.967 ekor) (Kementan 2012).

Pengembangan usaha perbibitan sapi potong dalam satu kawasan yang dikelola oleh masyarakat baik secara intensif maupun semi intensif merupakan salah satu upaya yang di tempuh untuk meningkatkan populasi sapi potong dan produksi daging dalam negeri. Upaya ini masih dihadapkan pada berbagai kendala yang disebabkan oleh berbagai faktor, antara lain sistem pemeliharaan ditingkat peternak pedesaan masih sebatas usaha sampingan, sebagai sumber tenaga kerja, sebagai sumber pupuk dan tabungan. Selain itu faktor ketersediaan hijauan pakan dan sistem pemberian pakan belum memperhatikan aspek nutrisi yang sesuai kebutuhan baik untuk produksi maupun repoduktivitas. Umumnya usaha perbibitan oleh peternak rakyat masih dengan skala usaha kecil, dimana tingkat pengetahuan dan kemampuan menjalankan usaha perbibitan menggunakan teknologi dan manajemen yang lebih kompleks masih sangat terbatas (Panjaitan 2010).

Pada kondisi peternakan rakyat, kekurangan nutrisi pakan pada sapi betina menyebabkan terjadinya penurunan nilai skor kondisi tubuh (body condition score/BCS) yang pada akhirnya berdampak pada terganggunya aktivitas reproduksi induk ditandai dengan kejadian berahi tenang (silent heat), oestrus post partum (OPP), days open (DO), service per conception (S/C) serta calving interval (CI) yang panjang (Putro 2009). Kurangnya asupan nutrisi pada induk selama masa bunting juga telah menyebabkan rendahnya berat lahir dan bahkan kasus kematian pada anak yang baru dilahirkan.

Penelitian ini bertujuan untuk mengetahui kinerja reproduksi sapi betina dan performa pedet pada usaha perbibitan sapi potong di Kabupaten Sigi yang merupakan lokasi kegiatan pendampingan pengembangan kawasan peternakan di Sulawesi Tengah.

\section{MATERI DAN METODE}

Penelitian dilaksanakan di salah satu lokasi kegiatan pendampingan pengembangan kawasan peternakan sapi potong di Sulawesi Tengah, yakni di Desa Pandere Kecamatan Gumbasa Kabupaten Sigi pada kelompok ternak Bualo Jaya. Pelaksanaan penelitian mulai tahun 2015 sampai 2016. Sebanyak 30 anggota kelompok ternak Bualo Jaya dijadikan responden yang dipilih secara sengaja dengan syarat memiliki 2-4 ekor sapi betina yang telah beranak satu kali. Sistem pemeliharaan sapi betina secara semi intensif, pada pagisiang hari dilepas/ikat pindah di kebun atau di lahan sawah saat panen, pada sore-malam hari ternak dikandangkan secara berkelompok. Pola introduksi berupa pemberian jerami 
fermentasi dan hijauan. Sistem perkawinan dengan kawin alam dan inseminasi buatan (IB).

Pengumpulan data karakteristik peternak responden yaitu umur, pendidikan, pengalaman beternak dan kepemilikan ternak; serta data kinerja reproduksi sapi betina; BCS, DO, OPP, kawin setelah beranak, S/C dan CI diperoleh dengan cara wawancara menggunakan daftar pertanyaan terstruktur (kuesioner). Ukuran linier tubuh sapi betina antara lain bobot badan (BB), lingkar dada (LD), tinggi gumba (TG), lebar panggul (LP) dan panjang badan (PB) diperoleh dengan cara mengukur tubuh ternak. Data performa pedet yakni jenis kelamin, bobot lahir (BL), panjang badan dan tinggi badan waktu lahir diperoleh dari data recording lahir selama kegiatan tahun 2015-2016. Data yang telah dikumpulkan dianalisis secara deskriptif dengan menggunakan Program XLSTAT for Windows version 5.03 (XLSTAT 2014).

\section{HASIL DAN PEMBAHASAN}

\section{Karakteristik peternak}

Pengkajian dilaksanakan di salah satu wilayah pengembangan kawasan peternakan Sulawesi Tengah yakni di Desa Pandere Kecamatan Gumbasa Kabupaten Sigi pada kelompok ternak Bualo Jaya. Dari 30 orang peternak responden sebagian besar bekerja sebagai petani dengan rata-rata umur 41,3 tahun, tingkat pendidikan SLTA dan pengalaman beternak selama 16,2 tahun. Beberapa hasil penelitian sebelumnya menggambarkan bahwa secara umum peternak pada umur tersebut termasuk golongan produktif. Takdir \& Munier (2013) melaporkan bahwa umur produktif peternak sapi pada kegiatan pendampingan PSDSK di Sulawesi Tengah rata-rata berumur 43,8 tahun. Menurut Soeharsono et al. (2013) umur rata-rata peternak adalah 41 tahun dengan tingkat pendidikan SMP-SMA memungkinkan peternak mudah menerima inovasi teknologi usaha tani menuju perbaikan, baik secara individu maupun kelompok. Rata-rata kepemilikan/penguasaan ternak 2-4 ekor per orang. Total populasi ternak yang dimiliki kelompok saat ini sebanyak 113 ekor, dengan struktur populasi seperti pada Gambar 1.



(A) Populasi

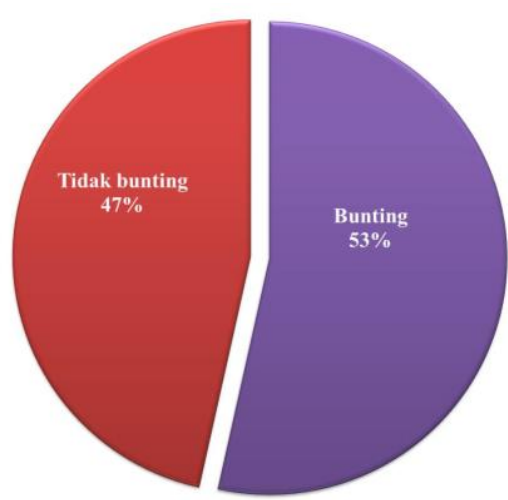

(B) Status fisiologi

Gambar 1. Populasi dan status fisiologi sapi betina milik responden

Jumlah populasi sapi betina induk sebanyak 43 ekor atau 38,05\% dari total populasi yang dimiliki responden termasuk cukup tinggi, sehingga peluang untuk menghasilkan anak juga relatif lebih besar (Gambar 1A). Sebanyak 66,7\% peternak responden mengawinkan ternak dengan sistem kawin alam dan 33,3\% dengan inseminasi buatan (IB). Dengan 
jumlah induk bunting yang dipelihara oleh kelompok sebanyak 23 ekor atau 53,0\% dari total betina induk (Gambar 1B) diharapkan dapat berkontribusi dalam meningkatkan jumlah populasi sapi potong setiap tahunnya, baik untuk penambahan jumlah populasi di kelompok, maupun untuk penambahan populasi di wilayah Kabupaten Sigi.

Jenis sapi yang dipelihara oleh peternak responden sebagian besar adalah sapi Peranakan Ongole (PO) dan sapi lokal Donggala. Sistem pemeliharaan secara semi intensif pada pagi hingga sore hari ternak dilepas atau diikat pindah untuk merumput di lahan perkebunan kelapa atau kakao, pematang sawah atau di lahan sawah setelah panen padi. Malam hari ternak dikandangkan secara berkelompok dalam kandang komunal milik kelompok. Pemberian pakan tambahan berupa dedak hanya seadanya dan dilakukan pada saat ternak berada dalam kandang. Menurut Aryogi et al. (2005) usaha sapi potong rakyat sebagian besar merupakan usaha yang bersifat turun temurun dengan pola pemeliharaan sesuai dengan kemampuan peternak terutama dalam hal pemberian pakan, hijauan bervariasi jenis dan jumlahnya

\section{Pemanfaatan pukan dan jerami padi}

Hasil kajian menunjukkan bahwa pemanfaatan pukan sebagai pupuk organik dan jerami padi sebagai pakan dapat meningkatkan produktivitas padi dan sapi potong (Tabel 1).

Tabel 1. Hasil usahatani padi dan sapi potong pada pola introduksi dan pola existing

\begin{tabular}{lcc}
\hline \hline Usaha tani & Pola introduksi & Pola existing \\
\hline Padi (ton/ha) & 4,43 & 3,71 \\
Sapi potong & & \\
PBB (kg/ekor/100 hari) & 37,46 & 37,10 \\
PBBH (kg/ekor/hari) & 0,37 & 0,37 \\
\hline
\end{tabular}

Pada Tabel 1 ditunjukkan bahwa pola introduksi memberikan hasil padi sebesar 4,43 ton/ha dan 3,71 ton/ha di pola existing. Hal ini menunjukkan bahwa pemanfaatan pukan mampu meningkatkan hasil produksi padi sebesar 0,72 ton/ha $(19,41 \%)$ dari pola existing. Pemberian jerami padi fermentasi sebagai pakan terdapat kecenderungan meningkatkan PBB yang lebih baik pada pola introduksi dibandingkan dengan pola existing. Hasil ini lebih tinggi dibandingkan dengan yang dilaporkan Zaini et al. (2002) peningkatan produksi tanaman padi sebesar 0,55 ton/ha pada musim tanam pertama dan 0,30 ton/ha pada musim tanam kedua dan hasil kajian Kariyasa \& Pasandaran (2004) dengan peningkatan 6,9-8,8\%. Basuni et al. (2010) melaporkan sistem integrasi padi dengan sapi potong memberikan hasil produksi padi 5,34 ton/ha, dengan dosis pupuk kandang 2 ton/ha. Hal ini secara ekonomi petani kooperator dapat menurunkan penggunaan pupuk anorganik sebesar 57,14\%.

Hasil kajian menunjukkan bahwa pemberian jerami fermentasi $10 \mathrm{~kg} / \mathrm{ekor} / \mathrm{hari}$ dan hijauan 5 $\mathrm{kg} / \mathrm{ekor} / \mathrm{hari}$ pada ternak sapi baik pola introduksi maupun pola petani memberikan PBBH yang tidak berbeda. Hal ini karena belum beradaptasinya ternak sapi dengan baik terhadap perlakuan pakan dan pola pemeliharaan yang diberikan. Hasil penelitian Darmawan (2003) menunjukkan bahwa pemberian jerami fermentasi $6 \mathrm{~kg} / \mathrm{ekor} / \mathrm{hari}$ dan dedak $3 \mathrm{~kg} / \mathrm{ekor} / \mathrm{hari}$ memberikan PBBH sebesar 0,43 kg/ekor dan Galib et al. (2006) dengan pemberian jerami fermentasi 6-8 kg/ekor/hari dan dedak $1 \mathrm{~kg} / \mathrm{ekor} /$ hari memberikan PBBH sebesar 0,41 kg/ekor. Hal ini menunjukkan bahwa pemanfaatan jerami padi sebagai pakan, khususnya dalam pengembangan sapi potong selain dapat mengatasi ketersediaan pakan di musim kemarau juga dapat meningkatkan PBBH sapi potong. Menurut Kariyasa (2003), bahwa pemanfaatan jerami padi dapat mengatasi permasalahan ketersediaan pakan berkisar 33,3 persen dari total rumput yang dibutuhkan. Model SITT yang dikembangkan petani di Jawa Tengah dan Jawa Timur mampu mengurangi penggunaan pupuk anorganik 25-35\% dan meningkatkan produktivitas padi 20-29\% (Adnyana 2003). 


\section{Kinerja reproduksi}

Penampilan reproduksi sapi potong yang perlu diperhatikan antara lain; S/C, CI dan jarak antara melahirkan sampai bunting kembali (Nuryadi \& Wahjuningsih 2011). Hasil penelitian menunjukkan bahwa rata-rata umur sapi betina yang dipelihara oleh 30 peternak responden adalah 3,52 tahun dengan performa dan kinerja reproduksi sebagaimana ditampilkan pada Tabel 2 .

Tabel 2. Kinerja reproduksi sapi betina induk pada peternak responden

\begin{tabular}{lc}
\hline \hline Uraian & Rata-rata \pm SD \\
\hline Umur (tahun) & $3,52 \pm 0,6$ \\
Skor kondisi tubuh & $3,5 \pm 0,5$ \\
Masa kosong/DO (bulan) & $7,2 \pm 0,7$ \\
Berahi setelah beranak/OPP (bulan) & $2,9 \pm 0,4$ \\
Kawin setelah beranak (bulan) & $3,3 \pm 0,4$ \\
Service per conception (kali) & $2,5 \pm 0,5$ \\
Jarak beranak/CI (bulan) & $16,5 \pm 0,5$ \\
\hline
\end{tabular}

Mengacu pada nilai S/C yang baik dan direkomendasikan untuk usaha breeding yakni di bawah 1,55 (Puslitbangnak 2010) maka nilai S/C 2,5 sapi betina induk pada peternak responden relatif masih sangat tinggi. Nilai $\mathrm{S} / \mathrm{C}$ sangat berpengaruh terhadap DO, sapi dengan nilai S/C 2 kali secara langsung telah berakibat pada panjangnya DO dan CI. Menurut Winugroho (2002) agar induk dapat beranak setiap tahun maka ternak tersebut harus dapat bunting dalam 90 hari post partum. Estrus pertama post partum harus sekitar 35 hari sehingga induk harus mempunyai kesempatan kawin dua kali.

Berdasarkan nilai S/C, DO, OPP, kawin setelah beranak dan CI yang diperoleh maka dapat dikatakan bahwa kinerja reproduksi sapi betina induk yang dipelihara peternak responden relatif masih rendah. Kondisi ini terjadi karena sebagian besar peternak responden belum melakukan pengelolaan reproduksi secara baik. Peternak sulit mendeteksi gejala berahi dan mengawinkan ternak tepat pada waktunya. Timbulnya gejala berahi pada ternak seringkali tidak diketahui oleh peternak. Hal ini disebabkan aktivitas peternak responden lebih banyak di sawah dan kebun. Peternak hampir tidak punya waktu untuk mengamati setiap saat ternak yang dipelihara, karena kebanyakan aktivitas peternak berada di lahan usaha tani sawah dan kebun (Takdir \& Munier 2013). Menurut Bagley \& Evans (2007) untuk memperbesar keberhasilan terjadinya kebuntingan adalah ketepatan mengawinkan sapi betina yakni 10-14 jam sejak tanda-tanda estrus muncul.

Dalam hal ukuran tubuh sapi betina yang dipelihara peternak responden ditampilkan pada Tabel 3.

Tabel 3. Ukuran linier tubuh sapi betina induk pada peternak responden

\begin{tabular}{lc}
\hline \hline Ukuran linier tubuh & Rata-rata \pm SD \\
\hline Bobot badan $(\mathrm{kg})$ & $234,3 \pm 61,5$ \\
Lingkar dada $(\mathrm{cm})$ & $146,2 \pm 13,1$ \\
Tinggi gumba $(\mathrm{cm})$ & $121,4 \pm 11,5$ \\
Lebar panggul $(\mathrm{cm})$ & $55,9 \pm 7,9$ \\
Panjang badan $(\mathrm{cm})$ & $100,7 \pm 13,5$ \\
\hline
\end{tabular}


Berdasarkan ukuran linier tubuh menunjukkan performa sapi betina umur di atas dua tahun yang dipelihara peternak responden termasuk dalam kategori normal dan memenuhi kriteria untuk dijadikan sapi induk dalam program perbibitan. Ukuran tubuh induk yang diperoleh tersebut sesuai standar nilai SNI 7356:2008 untuk induk sapi potong PO yakni lingkar dada 134-153 cm, tinggi gumba $119-126 \mathrm{~cm}$ dan panjang badan 125-135 $\mathrm{cm}$ (SNI 7356:2008).

\section{Performa pedet}

Data performa pedet yang lahir dari sapi betina induk pada peternak responden selama tahun 2015-2016 ditampilkan pada Tabel 4. Jumlah pedet yang lahir dari sapi betina induk yang dipelihara peternak responden selama tahun 2015-2016 sebanyak 35 ekor. Terjadi perbedaan dalam hal BL, PB dan TG pada pedet yang lahir tahun 2015 dan 2016. Pedet yang lahir tahun 2016 rata-rata memiliki BL dan PB lebih tinggi dibandingkan dengan tahun 2015. Rerata BL pedet yang diperoleh pada tahun 2015 adalah 22,29 $\pm 12,0 \mathrm{~kg}$ dan pada tahun 2016 diperoleh $25,07 \pm 9,0 \mathrm{~kg}$. Rata-rata BL yang diperoleh dalam penelitian ini relatif lebih besar dibandingkan dengan yang dilaporkan Hartati \& Dikman (2007), bahwa bobot lahir sapi PO di foundation stock pada kondisi pakan low external input adalah 23,19 kg. Perbedaan ini kemungkinan karena sebagian besar pedet yang lahir tahun 2016 dari hasil perkawinan IB, sedangkan pedet yang lahir pada tahun 2015 dari hasil kawin alam menggunakan pejantan yang tidak terseleksi.

Adanya pemberian pakan tambahan berupa dedak padi oleh peternak responden pada saat sapi dalam masa bunting juga diduga turut berpengaruh terhadap BL pedet saat lahir. Dari hasil wawancara, pada umumnya peternak hanya memberikan pakan tambahan berupa dedak padi seadanya saja saat ternak berada dalam kandang kelompok pada malam hari. Namun pada saat ternaknya dalam keadaan bunting, peternak responden selalu berusaha agar tetap dapat memberikan pakan tambahan dedak padi, walaupun jumlah dan cara pemberiannya belum sesuai. Menurut Utomo et al. (2006) bobot lahir ditentukan oleh kondisi pertumbuhan prenatal yang ditunjang suplai nutrisi dari induk serta kemampuan induk untuk menggunakannya.

Tabel 4. Performa pedet yang lahir selama tahun 2015-2016

\begin{tabular}{lcc}
\hline \hline \multirow{2}{*}{ Uraian } & \multicolumn{2}{c}{ Tahun lahir } \\
\cline { 2 - 3 } & 2015 & 2016 \\
\hline Jumlah lahir (ekor) & 20 & 15 \\
Bobot lahir (kg) & $22,29 \pm 12,0$ & $25,07 \pm 9,0$ \\
Panjang badan (cm) & $54,15 \pm 6,9$ & $54,53 \pm 7,1$ \\
Tinggi gumba (cm) & $62,43 \pm 11,5$ & $59,46 \pm 7,5$ \\
Ratio jantan dan betina (ekor) & $10: 10$ & $4: 11$ \\
Hasil perkawinan & & \\
Alam (ekor) & 14 & 7 \\
IB (ekor) & 6 & 8 \\
\hline
\end{tabular}

Rasio pedet jantan dan betina yang lahir tahun 2015 dapat dikatakan sebanding (jantan 10 ekor : betina 10 ekor), sedangkan pedet yang lahir tahun 2016 lebih didominasi oleh betina (jantan 4 ekor : betina 11 ekor). Keadaan ini diduga terjadi karena perubahan sistem perkawinan yang diterapkan oleh peternak responden. Hasil wawancara pada peternak 
responden diperoleh informasi bahwa pada tahun 2015 sebagian besar peternak responden mengawinkan ternaknya dengan cara kawin alam. Namun seiring dengan pelaksanaan program gertak berahi inseminasi buatan (GBIB) dan IB menggunakan sperma sexing pada tahun 2016, sebagian besar peternak mengawinkan ternaknya dengan cara IB menggunakan sperma sexing kromosom $\mathrm{X}$ (betina) oleh karena peternak menginginkan kelahiran anak sapi berjenis kelamin betina.

\section{KESIMPULAN}

Hasil penelitian disimpulkan bahwa kinerja reproduksi sapi betina pada usaha perbibitan sapi potong di Kabupaten Sigi relatif masih rendah. Dengan adanya tambahan pakan, kinerja meningkat namun masih diperlukan pengelolaan reproduksi yang lebih baik di kalangan peternak. Ukuran linier tubuh sapi betina sesuai nilai standar SNI sapi potong sehingga layak dijadikan sapi betina calon induk. Performa bobot lahir dan ukuran linier tubuh pedet yang lahir selama tahun 2015-2016 cukup baik.

\section{UCAPAN TERIMA KASIH}

Ucapan terima kasih kami sampaikan kepada Bapak Aslan Lasenggo (teknisi peternakan), Bapak Ahmad Ladjumpa (Ketua Kelompok Ternak Bualo Jaya) beserta seluruh anggotanya, jajaran Dinas Peternakan dan Kesejahteraan Hewan Kabupaten Sigi serta semua pihak yang telah membantu dan bekerjasama dalam pelaksanaan kegiatan pendampingan pengembangan kawasan peternakan sapi potong di Sulawesi Tengah selama tahun 2015-2016.

\section{DAFTAR PUSTAKA}

Aryogi, Sumadi, Hardjosubroto W. 2005. Performan sapi silangan Peranakan Ongole di dataran rendah (Studi kasus di Kecamatan Kota Anyar Kabupaten Probolinggo Jawa Timur). Dalam: Mathius IW, Bahri S, Tarmudji, Prasetyo LH, Triwulanningsih E, Tiesnamurti B, Sendow I, Suhardono, penyunting. Inovasi teknologi peternakan untuk meningkatkan kesejahteraan masyarakat dalam mewujudkan kemandirian dan ketahanan pangan nasional. Prosiding Seminar Nasional Teknologi Peternakan dan Veteriner. Bogor, 12-13 September 2005. Bogor (Indonesia): Puslitbangnak. hlm.

BPS Sulteng. 2016. Sulawesi tengah dalam angka. UD Rio. Palu (Indonesia): Badan Pusat Statistik Sulawesi Tengah.

Bagley CP, Evans RR. 2007. Replacement Heifer Selection and Management. Departement of Agricultural Sciences A.M. University Commerce. Mississippi State University [Internet]. [cited 7 Oktober 2010]. Available from: www.pfizerah.com/index_species.asp.drug.

Ditjen PKH. 2016. Statistik Peternakan dan Kesehatan Hewan 2016. Jakarta (Indonesia): Direktorat Jenderal Peternakan dan Kesehatan Hewan.

Hartati, Dikman DM. 2007. Performa pedet sapi Peranakan Ongole (PO) pada kondisi pakan low external input. Dalam: Darmono, Wina E, Nurhayati, Sani Y, Prasetyo LH, Triwulanningsih E, Sendow I, Natalia L, Priyanto D, Indraningsih, Herawati T, penyunting. Akselerasi agribisnis peternakan nasional melalui pengembangan dan penerapan IPTEK. Prosiding Seminar Nasional Teknologi Peternakan dan Veteriner. Bogor, 21-22 Agustus 2007. Bogor (Indonesia): Puslitbang Peternakan. hlm. 137-142.

Kementan. 2012. Pedoman pengembangan kawasan pertanian. Jakarta (Indonesia): Kementerian Pertanian. hlm. 66. 
Nuryadi, Wahjuningsih S. 2011. Penampilan reproduksi sapi Peranakan Ongole dan Peranakan Limosin di Kabupaten Malang. J Ternak Tropika. 12:76-81.

Panjaitan TS. 2010. Manajemen Umum Pembiakan Sapi Bali. Petunjuk Manajeman Umum Pembiakan Sapi Bali. BPTP Nusa Tenggara Barat, Balitbangtan 2010.

PSPK. 2011. Rilis akhir hasil sensus ternak tahun 2011. Jakarta (Indonesia): Kementerian Pertanian dan Badan Pusat Statistik.

Putro PP. 2009. Dampak Crossbreeding terhadap Reproduksi Induk Turunannya: Hasil Studi Klinis. Disampaikan pada Lokakarya Lustrum VIII Fakultas Peternakan UGM. Yogyakarta 8 Agustus 2009.

Puslitbangnak. 2010. Rekomendasi Teknologi Peternakan dan Veteriner Mendukung Program Swasembada Daging Sapi (PSDS) Tahun 2014. Bogor (Indonesia): Puslitbangnak.

SNI 7356. 2008. Bibit Sapi Peranakan Ongole. Jakarta (Indonesia): Badan Standardisasi Nasional Indonesia.

Soeharsono, Takdir M, Munier FF. 2013. Performan induk sapi lokal Donggala yang dipelihara secara ekstensif di lembah Palu Sulawesi Tengah. Dalam: Djufry F, Baco D, Limbongan J, Sahardi, Matheus Sariubang M, Ella A, Tandisau P, Nappu MB, Ishak ABL, et al., penyunting. Inovasi Pertanian Ramah Lingkungan. Prosiding Ekspose dan Seminar Nasional. Makassar, 19-21 Juni 2013. Bogor (Indonesia): Balai Besar Pengkajian dan Pengembangan Teknologi Pertanian. hlm. 218-224.

Takdir M, Munier FF. 2013. Kondisi peternak dan keragaan pengelolaan reproduksi sapi betina di lokasi pendampingan Program PSDS-K Sulawesi Tengah. Dalam: Mardiana, Haryono P, Padang IS, Irmadamayanti A, Dewi M, Biolan H, et al., penyunting. Akselerasi Inovasi dan Diseminasi Teknologi Menuju Kemandirian dan Ketahanan Pangan Berbasis Sumberdaya Genetik Lokal. Prosiding Seminar Nasional. Palu, 18 Maret 2013. Bogor (Indonesia): Balai Besar Pengkajian dan Pengembangan Teknologi Pertanian. hlm. 1101-1111.

Utomo B, Prawirodigdo S, Sarjana, Sutjadmogo. 2006. Perfomans pedet sapi perah dengan perlakuan induk saat masa akhir kebuntingan. Dalam: Mathius IW, Sendow I, Nurhayati, Murdiati TB, Thalib A, Beriajaya, Prasetyo LH, Darmono, Wina E, penyunting. Cakrawala baru IPTEK menunjang revitalisasi peternakan. Prosiding Seminar Nasional Teknologi Peternakan dan Veteriner. Bogor, 5-6 September 2006. Bogor (Indonesia): Puslitbangnak. hlm. 76-81.

Winugroho M. 2002. Strategi pemberian pakan tambahan untuk memperbaiki efisiensi reproduksi induk sapi. J Litbangtan. 21:19-23.

XLSTAT. 2014. XLSTAT for Windows Version 2014.5.03. Developed and Copyright by Addinsoft 1995-2014. Registered version. [Internet]. [cited 14 Oktober 2014]. Available from: www.xlstat.com.

\section{DISKUSI}

\section{Pertanyaan}

Berapa lama penelitian dilakukan? Terkait apa yang terdapat dalam metodologi, berapa jumlah kepemilikan ternak?

\section{Jawaban}

Penelitian dengan kolekting data dilakukan selama pendampingan yaitu tahun 2015-2016. Jumlah ternak dari 30 responden dengan rata-rata kepemilikan 3-4 ekor. 